during the $2 \mathrm{~h}$ of surgery and the radial pulse became impalpable 30 min after induction.

The abdominal wall was infiltrated with lignocaine and incised in the mid-line. 3 litres of semisolid food was removed from the stomach and exploration revealed gross gaseous distension of small and large bowel, with infarction of the small bowel, and gas bubbles in the mesenteric veins. The ischaemic bowel was decompressed and packed with hot towels without any improvement and the patient died $1 \mathrm{~h}$ after surgery had been abandoned.

Necropsy revealed extensive haemorrhage into the submucosal layers of the stomach and small intestine, and the stomach wall was torn. The whole bowel was invaded by Clostridium perfringens. There was also melanosis coli, a condition often associated with purgation.

The main cause of death was probably septicaemia, but the massive abdominal distension, diaphragmatic splinting, and high serum potassium may well have contributed to a fatal outcome.

Abdominal distension inhibits return along the inferior vena cava and in acute distension there is not the physiological adjustment that occurs in pregnancy, ascites, or large ovarian tumours. During laparoscopy cardiac output falls when intra-abdominal pressure increases. ${ }^{2,3}$ The risk of inhalation of gastric contents could be a major problem in bulimia nervosa because of the gastric atony. Such patients often vomit effortlessly, and Russell ${ }^{1}$ describes a patient who could empty her stomach at will simply by placing one foot on a chair and leaning forward. For this reason the left lateral position should be used for induction of anaesthesia in such cases, together with a cuffed endotracheal tube to divert stomach contents away from the larynx. ${ }^{4}$ Abdominal restriction can reduce total lung capacity ${ }^{5}$ by displacing the diaphragm upwards, and this can affect arterial oxygenation in conscious and anaesthetised patients. ${ }^{6}$ In this patient the cyanosis did not respond to oxygen.

The preoperative hyperkalaemia precluded the use of suxamethonium (this drug raises the serum potassium and may thus cause cardiac arrest). Intubation under local analgesia was not possible and general anaesthesia was used. The patient was then allowed to breathe spontaneously since slight manual pressure on the reservoir bag caused the peripheral pulses to disappear.

There are some comparisons between this case and "pig-bel", in which necrosis and invasion of the gut by $\mathrm{Cl}$ perfringens follow the ceremonial eating of unaccustomed large quantities of partly cooked pork in New Guinea.

Bulimia nervosa is infrequently diagnosed, though this does not mean that it is rare. It needs to be recognised and treated early, if only to avoid the need for general anaesthesia when the gorging results in an abdominal emergency.

I thank Prof J. Utting and Dr J. Hunter for their help and Mr I. W. MacPhee for permission to report this case.

Royal Liverpool Hospital*

GILLIAN M. EDWARDS

*Present address. Walton Hospital, Liverpool L9 1AE.

1. Russell G. Bulimia nervosa. Psychol Med 1979; 9: 429-48.

2 Kelman GR, Swapp GH, Smith I, Benzie RJ, Gordon NLM. Cardiac output and arterial blood gas tensions during laparoscopy. Br I Anaesth 1972; 44: 1155-61.

3. Lenz RJ, Thomas TA, Wilkuns DG. Cardiovascular changes during laparoscopy. Anaesthesia 1976; 31: 4-12.

4. Cucchıara RF. Simple technıque to minımıze tracheal aspiratıon. Anaesth Analg 1976; 55: $816-17$.

5 Bradley CA, Anthonisen NR. Rub cage and abdomınal restrictions have different effects on lung mechanics. F Appl Phystol 1980; 49: 946-52.

6. Drummond GB, Martın LVH. Pressure-volume relationships in the lung during laparoscopy. Br 7 Anaesth 1978; 50: 261-69.

\section{POSSIBLE MECHANISMS OF PRIMARY THALAMIC HAEMORRHAGE IN NEWBORN}

SIR,-The report of primary thalamic haemorrhage in the newborn by Dr Trounce and colleagues (Jan 26, p 190) suggests that the short-term prognosis for affected infants is favourable. This is in sharp contrast to previous reports of two infants who were severely neurologically impaired ${ }^{1,2}$ and subsequently died (Toce $S$, personal communication, and Donn SM, unpublished). Unlike Trounce's patients, these two infants were severly asphyxiated in the perinatal period. We recently observed thalamic haemorrhage in a premature infant, also severely asphyxiated as a result of abruptio placenta; there was no subependymal or intraventricular haemorrhage. She also displayed clinical findings consistent with thalamic injury-non-reactive pupils, impaired arousal, disordered thermoregulation, and absent spontaneous motor activity. She too died.

The differing outcomes of these two groups of patients suggest the possibility of two mechanisms of thalamic injury. In the first, injury seems to be primarily haemorrhagic, with the potential for recovery. In the second, hypoxic-ischaemic injury may lead to infarction of the thalamus, with haemorrhage occurring as a secondary event, and the destruction of the thalamus is irreversible.

Routine sonographic scanning, careful neurological follow-up, and application of newer brain imaging techniques, such as nuclear magnetic resonance and positron emission tomography, may help to resolve these issues.

Department of Pediatrics,

University of Michigan,

Ann Arbor, Michigan 48109, USA

STEVEN M. DONN

1. Kotagal $S$, Toce $S$, Kotagal $P$, Archer $C$. Symmetric bithalamic and striatal hemorrhage following perinatal hypoxia in a term infant. F Comput Assist Tomography 1983; 7 353-55.

2. Donn SM, Bowerman RA, DiPietro MA, Gebarskı SS: Sonographic appearance of neonatal thalamic-striatal hemorrhage. f Ulirasound Med 1984; 3: 231-33

\section{ATROPINE OR HYOSCINE IN TREATMENT OF ACUTE ORGANOPHOSPHATE POISONING?}

SIR,-Janowsky et al ${ }^{1}$ found that with a physostigmine dose three times the $100 \%$ lethal dose $\left(\mathrm{LD}_{100}\right)$ in mice, pretreatment with hyoscine was much more effective than atropine in preventing death. With an $\mathrm{LD}_{100}$ dose atropine and hyoscine in doses greater than $0.1 \mathrm{mg} / \mathrm{kg}$ were equally effective. These workers suggested that hyoscine may be a more effective antidote than atropine for poisoning with high doses of centrally acting cholinesterase inhibitors. Unfortunately, organophosphate poisoning in man differs markedly from their mouse model. The poison is often an irreversible cholinesterase inhibitor; treatment with anticholinergic drugs does not precede exposure and may have to be continued for several days or weeks. We therefore tested their suggestion in a model more akin to the human situation.

Dimethoate (O,O-dimethyl S-methylcarbamoylmethyl phosphorodithioate) is an insecticide which is a common cause of organ-

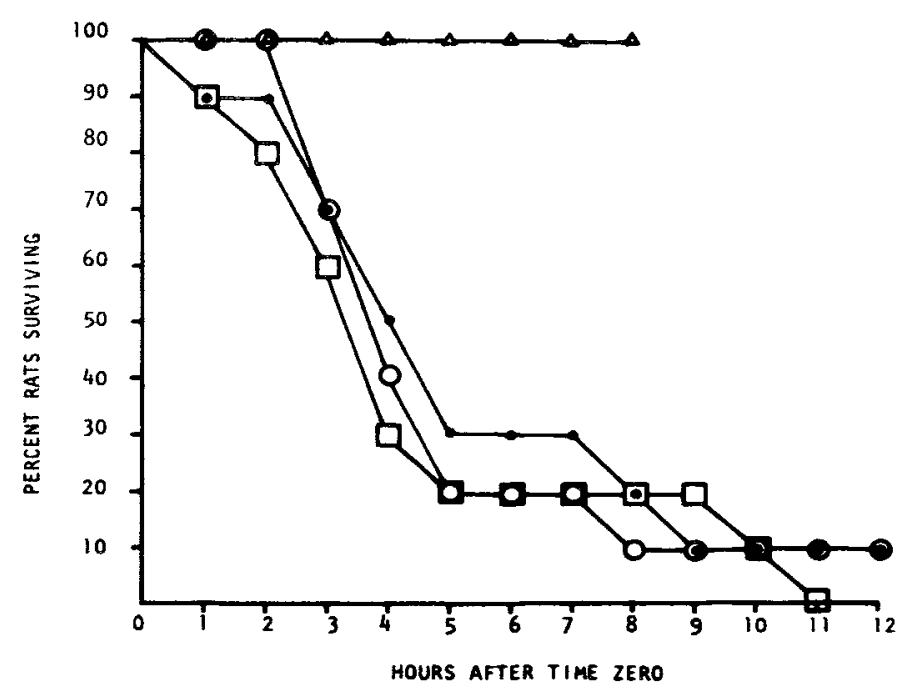

Effect of atropine and hyoscine on survival of rats given dimethoate $600 \mathrm{mg} / \mathrm{kg}$.

- $=$ group A (atropine); $\bigcirc-O=$ group B (hyoscine) $\square-\square=$ group $C$ (dimethoate only); $\Delta-\Delta=$ group $D$ (no dimethoate) atropine, hyoscine or saline. Time zero is $25 \mathrm{~m} i \mathrm{n}$ after dimethoate was given. 